University of Pennsylvania Carey Law School

Penn Law: Legal Scholarship Repository

Faculty Scholarship at Penn Law

$1-6-2020$

\title{
Justice Department's New Position on Patents, Standard Setting, and Injunctions
}

Herbert J. Hovenkamp

University of Pennsylvania Carey Law School

Follow this and additional works at: https://scholarship.law.upenn.edu/faculty_scholarship

Part of the Antitrust and Trade Regulation Commons, Economic Policy Commons, Intellectual

Property Law Commons, Law and Economics Commons, President/Executive Department Commons,

Public Policy Commons, Science and Technology Policy Commons, and the Technology and Innovation

Commons

\section{Repository Citation}

Hovenkamp, Herbert J., "Justice Department's New Position on Patents, Standard Setting, and Injunctions" (2020). Faculty Scholarship at Penn Law. 2149.

https://scholarship.law.upenn.edu/faculty_scholarship/2149

This Article is brought to you for free and open access by Penn Law: Legal Scholarship Repository. It has been accepted for inclusion in Faculty Scholarship at Penn Law by an authorized administrator of Penn Law: Legal Scholarship Repository. For more information, please contact PennlawIR@law.upenn.edu. 


\title{
Justice Department's New Position on Patents, Standard Setting, and Injunctions
}

Herbert Hovenkamp

\author{
REGULATORY REVIEW Jan. 6, 2019
}

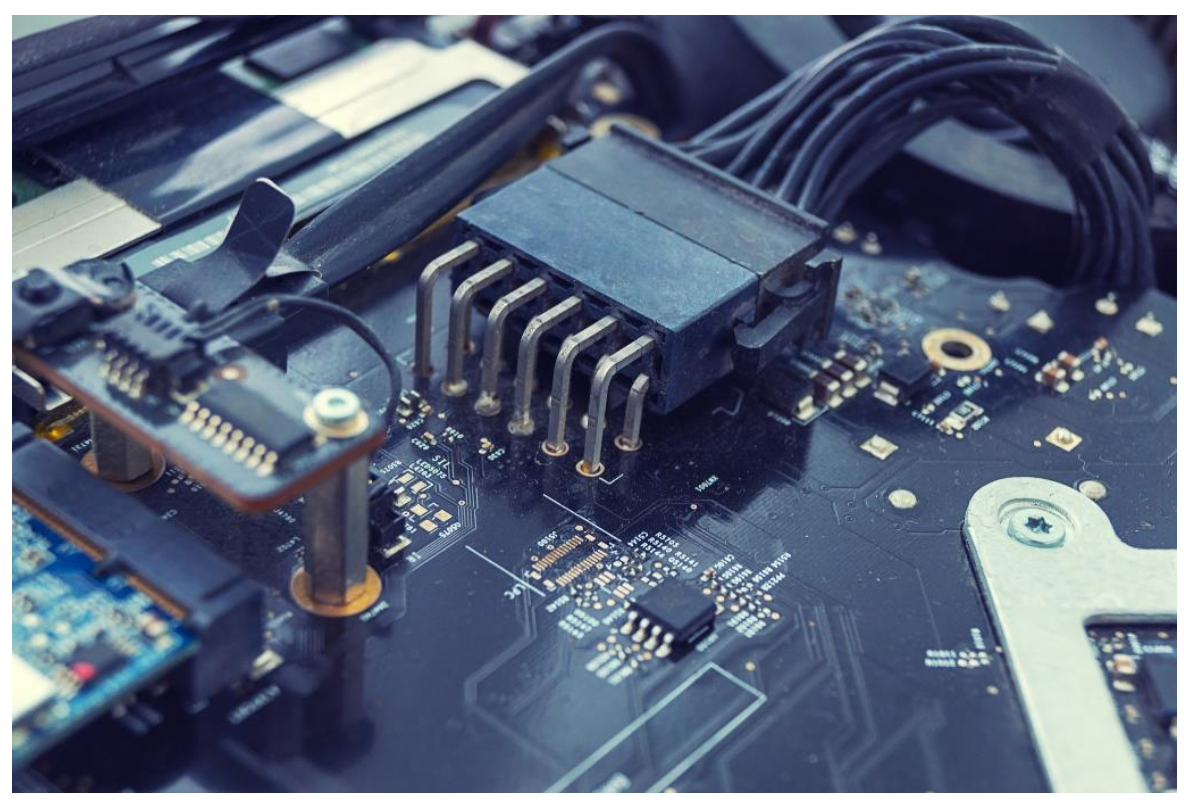

A new policy statement from the federal government contradicts established law on whether patentees can seek injunctions.

Photo: https://www.gettyimages.com/detail/photo/computer-chip$\underline{\text { repair-and-soldering-of-the-scheme-royalty-free-image/1125769029 }}$

A deep split in American innovation policy has arisen between new economy and old economy innovation. In a recent policy statement, the Antitrust Division of the Justice Department takes a position that tilts more toward the old economy.

In the old economy, networks play a smaller role. Products are covered by relatively few patents and individually the patents are durable 
because the products do not change all that rapidly. For example, a drug might be covered by a single principal patent on its molecule, and the drug might continue to be valuable long after its patent expired. This is true, for example, of Aspirin, Tylenol, and Ibuprofen. All became generic years ago but are still commercially viable on the market.

Information technologies are different in several respects. First, the sheer number of information technology patents is overwhelming. A common smartphone incorporates tens of thousands of them.

Second, these patents are often difficult to interpret, have high invalidity rates, and rapid obsolescence. Nevertheless, the cost of challenging them in litigation is high.

Finally, many information devices require interoperability with other devices made by different manufacturers. This usually requires producers to obtain many patent licenses from others.

Many of today's information technology industries, including cellular phones, computers, avionics and digital direction finders, video recorders and players, and televisions, among others, are covered by standard setting organizations (SSOs) intended to protect interoperability. A company might build a smartphone with the world's best features, but if it cannot be hooked into the system and connect with other phones it will be worthless. SSOs composed of many firms try to achieve interoperability, and usually they do so quite well.

The technologies adopted by new-economy SSOs are covered by many patents, and manufacturers who produce under these standards need access to them. SSOs require firms that want to be involved in setting the standard to license their patents out on "fair, reasonable, and nondiscriminatory" (FRAND) terms. These patents are called "standard essential patents," or SEPs. 
When a firm makes a FRAND commitment, it promises two things that the patent laws themselves do not require. First, it promises that it will license its patents to all firms who operate on the standard set by the SSO. Second, it promises it will offer its license on fair reasonable, and nondiscriminatory rates. If the parties cannot agree on a royalty, the dispute will be submitted to an independent third party such as a court or arbitrator. Nonparticipants are not required to submit patents to the FRAND system, but they then face the prospect that their technology will not be adopted as a standard. The structure of this system simply reflects rational behavior on the part of manufacturers. They prefer standards calling for technologies with known costs and guaranteed access.

Policing the FRAND process involves a combination of contract law, patent law, and sometimes antitrust law. As a result, both the Antitrust $\underline{\text { Division of the U.S. Department of Justice and the U.S. Federal Trade }}$ Commission (FTC) could get involved. Today there is a growing rift between the two agencies over how the FRAND process should function. The FTC tilts toward policies that favor new-economy informational technologies and places a premium on cooperative development. By contrast, the Justice Department is increasingly leaning toward old-economy perspectives that interpret cooperative agreements narrowly.

One divisive issue concerns when SSO participants who own standard essential patents may obtain an injunction against a patent infringer. Under the Patent Act, patent infringement is penalized by damages, but it can also lead to an injunction in some cases. A FRAND commitment, however, requires the patent owner to license to all participants in the standard upon payment of a FRAND royalty. The participants who use the technology required to meet the standard generally want a guarantee that they will not later be found to be infringers and forced to shut some of their technology down. By 
contrast, the patent holders may reasonably expect to receive a FRAND royalty once an amount has been properly determined.

In December 2019, the Justice Department, the U.S. Patent and Trademark Office, and the National Institute of Standards and Technology issued a formal policy statement on remedies for SEPs. The new statement declares that injunctions should be available for SEPs on the same terms as for patents generally. It also states in a footnote that the antitrust laws are not generally applicable to FRAND disputes.

The policy statement as a whole contains two problems: one is glaring omission, and the other is that what it says about antitrust liability is not a completely correct statement of the law. Both of these problems are highly relevant to the closely watched FTC v. Qualcomm litigation currently pending in the U.S. Court of Appeals for the Ninth Circuit.

The glaring omission in the policy statement is that it says absolutely nothing about the conduct of patent holders. The Patent Act authorizes injunctions "in accordance with the principles of equity." For centuries it has been governed by the principle that if plaintiffs want a court to force the defendant to do the right thing, then plaintiffs must be doing the right thing themselves: "He who seeks equity must do equity." Under this rule, which is often called "unclean hands," if a person is violating an ethical principle himself, then he cannot obtain an injunction from someone else. This rule has nothing to do with antitrust law and is not even limited to patent law. In the context of FRAND disputes, though, the rule becomes relevant when a patent owner seeks an injunction on a SEP but is not doing the things it has promised to do as a condition of having its patents declared standard essential.

In the current Qualcomm dispute, the FTC found that the company violated its FRAND obligation. Qualcomm refused to license its standard essential patents to competitors and refused to issue 
"exhaustive" licenses that impose no restrictions on subsequent product use. Furthermore, Qualcomm has insisted on certain types of "loyalty" as a condition for licensing, including prohibitions on the use of competitors' technology. Qualcomm used all of these requirements as leverage to obtain royalties that are well above the FRAND rate earned by better-behaved participants. All of this conduct is on the same patents for which Qualcomm might seek an injunction. The government's policy statement should have explained why the doctrine of unclean hands-which clearly applies in the Qualcomm case - would not prohibit a serial FRAND violator from obtaining an injunction.

On the issue of antitrust liability, the Justice Department is authorized to enforce the antitrust laws and certainly has the discretion not to prosecute a violation that occurs in the licensing of FRAND patents. But the FTC and private plaintiffs also have authority to enforce the antitrust laws. Although it is true that a FRAND dispute concerns a contract, the reason why a patentee is holding out for an injunction may nevertheless be anticompetitive, and the antitrust laws could clearly apply. In the Qualcomm case, a district court has already concluded that many of the company's FRAND-violating practices listed above also violate the antitrust laws-and on conventional antitrust grounds that have nothing to do with FRAND. For example, if the threat of an injunction is being used to enforce illegal tying, exclusive dealing, or another anticompetitive practice, that conduct will be fully reachable under the antitrust laws.

Guidelines from the government are very useful when they state the law or an agency's own enforcement position, or when they clarify ambiguities. But they are not legislation. Although they might bind the agencies who issue them, they do not bind others, particularly not when they are in conflict with law that is clearly established. 
Herbert Hovenkamp is the James G. Dinan University Professor at the University of Pennsylvania Law School and the Wharton School of the University of Pennsylvania. 